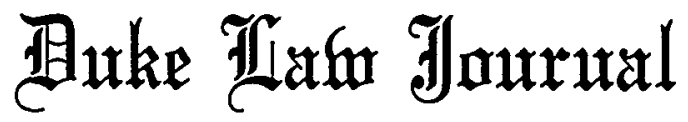

\section{DISGORGEMENT IN SECURITIES FRAUD ACTIONS BROUGHT BY THE SEC}

\author{
John D. Ellsworth*
}

Roughly a decade ago the Securities and Exchange Commission first argued in federal court for the right to seek restitution of the ill-gotten profits of securities law violators. ${ }^{1}$ The Commission eventually won that argument, ${ }^{2}$ and it has been successful in subsequent cases as well. ${ }^{3}$ Encouraged

* Member, District of Columbia and Nebraska Bars. The author wishes to express his appreciation for the assistance of Murray Drabkin, Esq. in the preparation of this Article.

1. SEC Pretrial Memorandum of Law, April 25, 1966, SEC v. Texas Gulf Sulphur Co., 258 F. Supp. 262 (S.D.N.Y. 1966); aff'd in part and rev'd in part, 401 F.2d 833 (2d Cir.), cert. denied, 394 U.S. 976 (1968). The SEC's complaint in Texas Gulf Sulphur was filed on April 19, 1965. See also SEC v. Golconda Mining Co., SEC Litigation Release 3235 (May 19, 1965) (restitution sought in an action based on insider trading-consent judgment); $c f$. SEC v. Golconda Mining Co., 327 F. Supp. 257 (S.D.N.Y. 1971).

A much earlier effort by the SEC to achievc such a right was abortive. In SEC v. Robert Collier \& Co., Inc., 76 F.2d 939 (2d Cir. 1935), the SEC did request, in its complaint for an injunction based in part on anti-fraud violations, an impoundment by the court of receipts from allegedly illegal sales. The defendants entered into a consent decree which directed them to return to subscribers the remaining balance of those receipts. See 3 L. Loss, SEcuRITIES REgulation 1828 n.483 (2d ed. 1961).

Prior to filing the Texas Gulf Sulphur case, the Commission had established that it could seek relief ancillary to an injunctive action in the form of court-appointed receivers in extraordinary cases where corporate assets would be jeoparized if left unprotected against future fraudulent activities. Esbitt v. Dutch-American Mercantile Corp., 335 F.2d 141 (2d Cir. 1964); SEC v. Keller Corp., 323 F.2d 397 (7th Cir. 1963); Los Angeles Trust Deed \& Mortgage Exchange v. SEC, 285 F.2d 162 (9th Cir.), cert. denied, 366 U.S. 919 (1961); cf. SEC v. Bennett \& Co., 207 F. Supp. 919 (D.N.J. 1962) (appointment of receiver denied as not necessary under the circumstances).

2. SEC v. Texas Gulf Sulphur Co., 312 F. Supp. 77, $92-94$ (S.D.N.Y. 1970), aff'd on this point, rev'd in part, 446 F.2d 1301, 1307-08 (2d Cir.), cert. denied, 404 U.S. 1005 (1971).

3. SEC v. Shapiro, 494 F.2d 1301 (2d Cir. 1974); Chris-Craft Industries, Inc. v. Piper Aircraft Corp., 480 F.2d 341, 390-92 (2d Cir.), cert. denied, 414 U.S. 910 (1973); SEC v. Manor Nursing Centers, Inc., 458 F.2d 1082, $1103-06$ (2d Cir. 1972); SEC v. Penn Central Co., [19761977 Transfer Binder] Fed. SEC. L. Rep. (CCH) I 95,867 (E.D. Pa. Dec. 28, 1976); SEC v. 
by an unbroken string of victories, the SEC has aggressively pursued this equitable form of relief, until today the demand for restitution, or "disgorgement," has assumed a prominent and still expanding role in the Commission's enforcement program. ${ }^{4}$

\section{Development of the Disgorgement Concept IN SECURITIES FRAUd CASES}

Nowhere within the statutory framework of the federal securities laws ${ }^{5}$ did Congress provide that the SEC would have the power to make a violator of the anti-fraud provisions disgorge tainted profits. Nor is there any direct reference in the legislative history surrounding the passage of the 1933 or 1934 Acts which would encourage the utilization of such an enforcement tool by the SEC. ${ }^{6}$ It would appear that this dearth of legislative support dissuaded the Commission for some three decades from testing in court the right to obtain such relief. That is not to say, however, that during this long period the Commission was necessarily content with obtaining only injunctions against the perpetrators of securities fraud.

Commonwealth Chemical Securities, Inc., 410 F. Supp. 1002, 1021 (S.D.N.Y. 1976); SEC v. General Refractories Co., 400 F. Supp. 1248, 1260 (D.D.C. 1975); SEC v. Blatt, [1975-1976 Transfer Binder] FED. SEC. L. REP. (CCH) I 95,281, at 98,444 (S.D. Fla. July 24, 1975); SEC v. Weisberger, [1974-1975 Transfer Binder] FED. SEC. L. REP. (CCH) ף 95,108, at 97,944 (S.D.N.Y. June 3, 1975); SEC v. R.J. Allen \& Assocs., Inc., 386 F. Supp. 866, 880-81 (S.D. Fla. 1974); SEC v. Golconda Mining Co., 327 F. Supp. 257 (S.D.N.Y. 1971); see also SEC v. Quing N. Wong, 252 F. Supp. 608 (D.P.R. 1966); ALI FED. SEC. CODE § 1515(i) (revised text of Tent. Draft Nos. 1-3 (1974)).

The Commission's only setback was short-lived. In SEC v. National Securities, Inc., 252 F. Supp. 623 (D. Ariz. 1966), the court denied an SEC request to invalidate a merger of two insurance companies on grounds of fraudulent misrepresentations and omissions in the proxy materials because it would violate certain provisions of the McCarran Act (15 U.S.C. \$ 1012(b) (1970)). The Court also rejected the SEC's prayer for an accounting for unjust enrichment as inappropriate and outside the scope of section 21(e) of the 1934 Act. On appeal the Ninth Circuit affirmed the rejection of the request to invalidate the merger on the basis of the prohibition in the McCarran Act. 387 F.2d 25 (9th Cir. 1967). The opinion did not discuss the lower court's denial of the disgorgement prayer. The Supreme Court reversed and remanded, finding that the relief sought was not prohibited by the McCarran Act. 393 U.S. 453 (1969). Subsequent proceedings in the case on remand, if any, were not reported.

4. A comparison by the author of SEC Litigation Releases for 1972 and 1975 indicates that in those injunctive actions based at least in part on allegations of fraud, some form of restitution was sought in approximately 20 percent of the cases in 1972, whereas by 1975 this figure had increased to approximately 32 percent.

5. Securities Act of 1933, 15 U.S.C. $\$ \S 77 a-77 a a(1970)$; Securities Exchange Act of 1934, 15 U.S.C. $\$ \S 78 \mathrm{a}-78 \mathrm{hh}$ (1970); Public Utility Holding Company Act of 1935, 15 U.S.C. $\S \S 79$ 79z-6 (1970); Trust Indenture Act of 1939, 15 U.S.C. \$§ 77aaa-77bbbb (1970); Investment Company Act of 1940,15 U.S.C. $\$ \S 80 \mathrm{a}-1$ to $80 \mathrm{a}-52$ (1970) (section $42(\mathrm{e})$ of this statute empowers a court of equity to take jurisdiction and possession of an investment company and to appoint a trustee to dispose of any or all of its assets); Investment Advisers Act of 1940, 15 U.S.C. $\$ \S 80 \mathrm{~b}-1$ to $80 \mathrm{~b}-21$ (1970).

6. In fact, the legislative history of the 1934 Act has been cited against the SEC's position on disgorgement. See SEC v. Texas Gulf Sulphur Co., 446 F.2d 130I, 1307 \& n.7 (2d Cir. 1971). 


\section{A. Cases Prior to Texas Gulf Sulphur}

Even in its early days, the Commission was orcasionally able to achieve consensual restitution when challenging securities transactions. In Ward La France Truck Corp. ${ }^{7}$ for instance, the Commission dropped a would-be enforcement action when the alleged violators agreed to restitution. In that case insiders used their confidential knowledge of the corporation's rapidly expanding wartime business to take advantage of the other shareholders. They authorized a broker to purchase stock for their benefit at what were later found to be unfair prices. Once the SEC began to investigate, the insiders and a successor company agreed to pay back to the innocent shareholders profits of approximately $\$ 165,000$ which they had garnered through the improper trading. ${ }^{8}$ The formula used in computing these profits was solely that of the insiders, and was not passed upon by the Commission. ${ }^{9}$

Another early example of the SEC's ability to obtain voluntary restitution is found in SEC v. First Investment Co. of Concord. ${ }^{10}$ There the Commission was seeking injunctive relief in a complaint which alleged fraudulent purchases on inside information from May 21, 1942 to the end of 1944. Jackman, a defendant who had traded on the inside information through the First Investment Company, agreed in a consent decree filed jointly with the complaint to make restitution to all security holders of record whose shares were purchased from November 1, 1940 to January 1, 1945 , a period even longer than that alleged in the complaint. Jackman further agreed that the amount of the restitution would be the difference between the amount paid to the security holders and the value of the securities. The value was determined not as of the date that the inside information became public, but rather on the date of liquidation of the company which the securities represented. This formula had the effect of further increasing the aggregate profit Jackman agreed to give up. Despite these occasional successes, however, the Commission's court enforcement activities during this period were limited mainly to seeking injunctive relief alone. ${ }^{11}$

In the early 1960 s the Commission's policy of friendly persuasion to

7. I3 S.E.C. 373 (1943).

8. Id. at 378 .

9. Id. at $378 \mathrm{n} .5$.

10. SEC Litigation Release No. 281 (June 20, 1945).

11. The Commission was able to achieve some impressive recoveries of allegedly fraudulent gains through consents to restitution counts which were tentatively included in its complaints shortly before commencement of the Texas Gulf Sulphur litigation. See SEC v. Skagit Valley Telephone Co., SEC Litigation Release Nos. 3393 (Dec. 21, 1965), 3482 (Apr. 8, 1966) $(\$ 450,000)$; SEC v. VTR, Inc., SEC Litigation Release No. 3311 (Sept. 8, 1965) (\$1 million plus).

Voluntary restitution was more commonly achieved by the SEC in cases involving the violation of the registration provisions of Section 5 of the 1933 Act. For a collection of these cases, see 3 L. Loss, supra note 1, at 1824 n. 469. 
achieve restitution came under criticism from securities law expert Professor Louis Loss. In the 1961 edition of his treatise, Loss argued convincingly that the SEC, by virtue of two Supreme Court decisions ${ }^{12}$ and the general equity jurisdiction of all federal courts, possessed the requisite legal power to obtain enforced restitution and that the Commission had been overly cautious in not seeking such a remedy for securities violations. ${ }^{13} \mathrm{He}$ noted that the SEC was in the best position to vindicate investor rights under the securities statutes when the violation involved "many victims, each having lost too small an amount to warrant the trouble and expense of a private lawsuit." 14 Loss did recognize that the policy restraints against the SEC becoming a "private collection agency," as voiced by one of its chairmen, William Cary, ${ }^{15}$ deserved some weight where only a single, isolated transaction was involved. ${ }^{16}$ But in the commonplace situation where there were many victims, each with small losses, Cary, too, tended to agree with Loss that an action by the Commission to secure redress would be justified. ${ }^{17}$

Professor Loss saw support for his claim that the SEC was not limited to injunctions alone in combating securities fraud in Porter $v$. Warner Holding Co. ${ }^{18}$ In Porter, the Administrator of the Office of Price Administration had instituted an injunctive action against a landlord for excessive rent charges under section 205(a) of the Emergency Price Control Act of 1942. ${ }^{19}$ The Administrator also sought a refund of all those amounts collected by the lessor which were in excess of the maximum rents established by federal regulation. The Price Control Act specifically provided that individuals could bring their own actions to recover excess rents; ${ }^{20}$ it did not mention a similar right for the Administrator. Nevertheless, the Supreme Court found that he was equally entitled to sue for restitution despite this lack of explicit statutory authority. The Court initially noted the inherent equitable powers of the district court to fashion relief necessary under the circumstances and not to be denied or limited in the absence of a clear legislative command. ${ }^{21}$ But the Court emphasized somewhat the fact that the section of the statute authorizing injunctive relief also authorized the district

12. Mitchell v. Robert DeMario Jewelry, Inc., 361 U.S. 288 (1960); Porter v, Warner Holding Co., 328 U.S. 395 (1946).

13. 3 L. Loss, supra note 1 , at 1827-29. '

14. Id.

15. Cary, Book Review, 75 HARv. L. Rev. 857 (1962). See also Speech of SEC Commissioner Richard B. Smith at the Program of Continuing Legal Education of the California Bar, at Los Angeles, Jan. 12, 1968. "The Commission attempts to avoid being a collection agency for injured investors . . . " (on file at the SEC library, Washington, D.C.).

16. 3 L. Loss, supra note 1 , at 1828-29.

17. Cary, supra note 15 , at 861 .

18. 328 U.S. 395 (1946).

19. 77 Pub. L. No. 421, 56 Stat. § 205(a), 23, 33 (1942) (terminated 1947).

20. Id. $\$ 205(\mathrm{e}), 56$ Stat. at 34, as amended by Stabilization Extension Act of 1944, 78 Pub.

L. No. $383,108,58$ Stat. $632,640-41$.

21. 328 U.S. at $397-98$. 
court, upon a proper showing, to grant "a permanent or temporary injunction, restraining order, or other order. "22 The term "other order" was seen as contemplating a remedy entered in the exercise of the district court's equity discretion. ${ }^{23}$ Moreover, the legislative history cited by the Court afforded additional support for this view by stating that: "Such courts are given jurisdiction to issue whatever order to enforce compliance is proper under the circumstances of each particular case." 24 Neither the statutory language nor the legislative history of the 1933 or 1934 Acts, however, could offer such assistance to the SEC's cause.

Several other Supreme Court decisions of the Porter vintage appear to have figured into the Commission's eventual support of the disgorgement concept. ${ }^{25}$ In Deckert v. Independence Shares Corp..${ }^{26}$ the Court answered affirmatively the question of whether the 1933 Act authorized a purchaser of securities to maintain a suit in equity to rescind a fraudulent sale and secure restitution of the consideration paid. ${ }^{27}$ However, Deckert involved the remedial powers of a purchaser of securities in the context of an acknowledged right of recovery afforded by section 12(2) of the Act. ${ }^{28}$ Thus, the Court's decision in favor of petitioner's broad implied powers to enforce that right of recovery was of only marginal assistance to the SEC, which had yet to establish clearly that a similar right existed for it as well.

In Schine Chain Theaters, Inc. v. United States, ${ }^{29}$ which involved Sherman Act violations, the Court again recognized the inherent limitations of an injunctive action by the government. It said that because of these limitations, courts must resort to more effective equitable remedies even though they are not specifically provided for in the statute. Mr. Justice Douglas articulated the need for such extra-statutory relief:

If all that was done was to forbid a repetition of the illegal conduct, those who had unlawfully built their empires could preserve them intact. They could retain the full dividends of their monopolistic practice and profit from the unlawful restraints of trade which they had inflicted on competitors. Such a course would make enforcement of the Act a futile thing unless perchance the United States moved in at the incipient stages of the unlawful project.

To require divestiture of theatres unlawfully acquired is not to add to the penalties that Congress has provided in the antitrust laws. Like

22. Id. at 399 (quoting Emergency Price Control Act of 1942, § 205(a) 77 Pub. L. No. 421, § 205(a), 56 Stat. 23, 33 (emphasis added)).

23. Id. at 399-400.

24. Id. at 401 (quoting S. REP. No. 931, 77th Cong., 2d Sess. 10 (1942)).

25. See cases cited in SEC Pretrial Memorandum of Law, supra note 1, at 48-55.

26. 311 U.S. 282 (1940).

27. Id. at $289-90$.

28. 15 U.S.C. $\$ 771(2)(1970)$.

29. 334 U.S. 110 (1948). 
restitution it merely deprives a defendant of the gains from his wrongful conduct. It is an equitable remedy designed in the public interest to undo what could have been prevented had the defendants not outdistanced the government in their unlawful project. ${ }^{30}$

In 1960 the Supreme Court decided Mitchell v. Robert DeMario Jewelry, Inc. ${ }^{31}$ the other case referred to by Professor Loss in this context. ${ }^{32}$ Mitchell upheld the right of the Secretary of Labor, while attempting to enjoin certain violations of the Fair Labor Standards Act, also to seek a court order requiring that the guilty employer reimburse his employees for wages lost as a consequence of his unlawful discharges. The Court relied primarily upon Porter $v$. Warner Holding $\mathrm{Co}^{33}$ and, of particular importance to the SEC, the Court stated that it placed no significance on the fact that Porter had considered a wartime statute or that the language in the Emergency Price Control Act of 1942 confirmed the power to order reimbursement. ${ }^{34}$ In the latter context, the Mitchell Court stated broadly that "[w]hen Congress entrusts to an equity court the enforcement of prohibitions contained in a regulatory enactment, it must be taken to have acted cognizant of the historic power of equity to provide complete relief in light of the statutory purposes." 35 Both the 1933 and 1934 Acts contained from their inception provisions to the effect that the remedies provided for in the statute supplemented all other remedies that might exist in equity. ${ }^{36}$

In 1964, yet another decision was handed down by the Supreme Court in favor of allowing comprehensive remedies to enforce a federal regulatory statute, this time under the 1934 Act. In J.I. Case Co. v. Borak, ${ }^{37}$ shareholders brought a complaint against their corporation for violation of section 14(a) of the 1934 Act. They claimed the corporation used allegedly false and misleading proxy solicitation material in a proposed merger. The plaintiffs sought damages and declaratory and equitable relief under section 27 of the Act. ${ }^{38}$ The Court, citing the Deckert, Mitchell, Porter and Schine cases, found that the plaintiffs were entitled to bring an action for the alleged violation of section 14(a) and that the relief sought would serve as a "most effective weapon" in the enforcement of the proxy requirements. ${ }^{39}$ It went on to state: "It is for the federal courts "to adjust their remedies so as to grant the necessary relief' where federally secured rights are invaded." 40

30. Id. at 128.

31. 361 U.S. 288 (1960).

32. 3 L. Loss, supra note 1 , at 1827 n.478. See text accompanying note 12 supra.

33. 328 U.S. 395 (1946). See notes 18-24 supra and accompanying text.

34. 361 U.S. at 291 .

35. Id. at 291-92.

36. 1933 Act $\S 16,15$ U.S.C. $\S 77$ p (1970); 1934 Act $\S 28(a), 15$ U.S.C. $\S 78 b b(a)(1970)$.

37. 377 U.S. 426 (1964).

38. 15 U.S.C. $\$ 78 \mathrm{aa}(1970)$.

39. 377 U.S. at 433.

40. Id. (quoting Bell v. Hood, 327 U.S. 678, 684 (1946)). 
This line of authority from the Supreme Court made it increasingly likely that an SEC prayer for resitution of fraudulently obtained profits would receive a friendly reception in federal court. Meanwhile, the Commission's own somewhat negative attitude toward asserting such relief was also undergoing a change. At least one of the reasons for the change appears to have been a growing disenchantment with the deterrent effect of a mere consent decree. ${ }^{41}$

\section{B. The Effect of Texas Gulf Suphur on the Commission's Position on Disgorgement}

The insider trading surrounding Texas Gulf Sulphur's great Canadian mineral discovery was the final impetus that broke new ground. The Commission's complaint in the Texas Gulf Sulphur litigation, filed in April of 1965 , sought rescission and restitution with respect to the allegedly fraudulent transactions in addition to the standard injunctive relief. The salient facts in the case which bear on the question of disgorgement are as follows. With confidential information of the tremendous size of the discovery and its obvious prospective effect on Texas Gulf Sulphur's stock, company insiders purchased stock and calls or accepted Texas Gulf Sulphur stock options without first disclosing this material information. The purchases were made anonymously in the public market in which Texas Gulf Sulphur's stock was traded. Some of the insiders also recommended Texas Gulf Sulphur stock to friends and relatives who then bought for themselves and in some instances prompted others to buy. ${ }^{42}$

This factual setting, involving as it did open market purchases with no privity existing between the buyer and seller, the likelihood that the defrauded sellers were scattered about with relatively small individual losses at stake, and the fact that sellers' losses resulted not from being defrauded of actual cash but from being defrauded of the opportunity to make greater paper profits, was precisely the type of setting that Professors Loss and Cary thought would justify, from a policy standpoint, an SEC disgorgement action. ${ }^{43}$ Surprisingly, the contention that the Comission should step in

41. Stanley Sporkin, Director of the Division of Enforcement of the SEC, has noted that: "It used to be that we were satisfied with merely going into court, obtaining a consent decree and leaving it up to the private bar to sue and obtain money damages. But we have found that in many cases this approach seems to be a waste of effort and detrimental to the interests of the investing public." Sporkin, SEC Developments in Litigation and the Molding of Remedies, 29 Bus. LAW. 121, 122 (Special Issue, Mar. 1974).

In 1959 the Commission said, in discussing efforts to control the "boiler room" or high pressure securities sales methods usually accompanied by gross misrepresentations: "The Commission has found that resort to the civil injunction and administrative proceeding, no matter how vigorously employed, is not completely effective in halting the operation of boiler rooms." 25 SEC ANN. REP. 3 (1959).

42. The facts relevant to the fraud issue in Texas Gulf Sulphur have been carefully stated in the two decisions of District Judge Bonsal. See 258 F. Supp. 262, 268-75 (S.D.N.Y. 1966) and 312 F. Supp. 77, 80-84 (S.D.N.Y. 1970).

43. See text accompanying notes 15-17 supra. 
when there is the likelihood of apathy or indifference on the part of injured investors towards bringing a private action actually turned out to be quite inappropriate in the Texas Gulf Sulphur case. Judge Bonsal, who tried the case, noted that at least 49 private actions had been filed against Texas Gulf Sulphur, the individual defendants and others by the summer of $1966 .{ }^{44} \mathrm{The}$ fact that numerous private enforcement actions had been initiated placed the SEC in a patently duplicative role, and also should have hoisted into prominence the ancient rule that equity ought not intervene where an adequate legal remedy exists. ${ }^{45}$ Nevertheless, Judge Bonsal found in favor of the SEC's assertion of its own claim for restitution as relief ancillary to its injunctive action. ${ }^{46}$ The court set forth an array of authority, including those cases which were discussed previously, ${ }^{47}$ to support its conclusion that the Commission was indeed entitled to pursue and obtain court-enforced restitution..$^{48}$ The court was apparently sufficiently convinced of the Commission's right to disgorgement that, without any further discussion, it also applied the remedy against those defendants as to whom it had denied the SEC's request for permanent injunctions. ${ }^{49}$

The Commission's novel position on restitution was first formally explained in its Pre-Trial Memorandum to the court in Texas Gulf Sulphur. It made two fundamental points in that statement to the court: first, through disgorgement it sought to deprive defendants who engaged in fraudulent securities transactions of their profits "in order to prevent future violations of the law by those who have already violated Rule $10 \mathrm{~b}-5$ and to deter violations by others who may contemplate them . . .";50 and second, it was not acting "as an instrument for particular individuals but only to enforce and apply Section 10(b) and Rule 10b-5 in the public interest." 51 Several years later the Commission reiterated these fundamental purposes in an amicus brief in support of greater private remedies in class actions:

44. 258 F. Supp. at 267 n. 1 .

45. On the other hand, the SEC's statutory remedy, namely an injunction, was recognized as inadequate unless supplemented by restitution granted only through the court's powers in equity.

46. 312 F. Supp. at 92.

47. See text accompanying notes 18-40 supra.

48. 312 F. Supp. at 91-92.

49. Id. at 97-99. Subsequent securities cases have not predicated equitable relief ancillary to an injunctive claim on actually obtaining an injunction. Chris-Craft Industries, Inc. v. Piper Aircraft Corp., 480 F.2d 341, 390-91 (2d Cir.), cert. denied, 414 U.S. 910 (1973); SEC v. Manor Nursing Centers, Inc., 458 F.2d 1082, 1100, 1104 (2d Cir. 1972). Cf. United States v. Moore, 340 U.S. 616, 620 n.6 (1951) (restitution ordered in action under Housing and Rent Act of 1947). But see Note, Ancillary Relief in SEC Injunctive Suits for Violation of Rule 10b-5, 79 HARV. L. REv. 656, 657-58 (1966); Comment, SEC Enforcement of the Rule 10b-5 Duty to Disclose Material Information-Remedies and the Texas Gulf Sulphur Case, 65 MiCH. L. REv. 944,949 (1967) (both articles suggesting that the court's equitable jurisdiction would cease upon its determination not to issue an injunction).

50. SEC Pretrial Memorandum of Law, supra note 1, at 52.

51. Id. at 51. 
While in rare cases, as an adjunct to injunctive relief, the Commission has urged a court to deprive violators of their illegal gains by directing that these be paid to individuals who have been injured by their violations, even in such cases the Commission does not seek to make the investors whole; it seeks merely to deter violations by making violations unprofitable. 52

In its Annual Report to Congress for the year 1975, the Commission continued to emphasize its original objectives:

The SEC's primary function is to protect the public from fraudulent and other unlawful practices and not to obtain damages for injured individuals. Thus, a request that disgorgement be required is predicated on the need to deprive defendants of profits derived by their unlawful conduct and to protect the public by deterring such conduct by others..$^{53}$

Identical language had also appeared in each of the three preceding SEC Annual Reports. ${ }^{54}$ It would appear that beginning with Texas Gulf Sulphur the SEC has steadfastly adhered to the same position: that it seeks the disgorgement of profits to deter unlawful conduct and that it is not intent on obtaining recoveries for private individuals.

The SEC's desire to deter securities fraud violators through use of the disgorgement technique is self-evident. There are a number of perhaps less apparent reasons which explain why the Commission wants to dispel the notion that it sues on behalf of injured investors in bringing an action for disgorgement. In our legal system private parties are largely responsible for vindicating their own civilly-infringed rights. The Supreme Court has rejected the notion that a federal agency vested with authority to protect the public interest can use that authority to act primarily for the benefit of a wronged individual. In Federal Trade Commission v. Klesner, 55 for example, the FTC intervened in a bitter personal feud between two Washington, D.C. businessmen. It ordered one of them to cease and desist from future use of the business name used by the other, claiming that the same names caused confusion to the public. The Court ruled against the Commission, stating that it was not empowered to redress a private wrong under its enabling statute even though the wrong may have an incidental adverse effect on the public:

[T] he mere fact that it is to the interest of the community that private rights shall be respected is not enough to support a finding of public interest. To justify filing a complaint the public interest must be specific and substantial. ${ }^{56}$

52. Dolgow v. Anderson, 43 F.R.D. 472,483 (E.D.N.Y. 1968), rev'd on other grounds, 438 F.2d 825 (2d Cir. 1970) (emphasis by court).

53. 41 SEC ANN. Rep. 97-98 (1975).

54. 40 SEC ANN. Rep. 75 (1974); 39 SEC ANn. Rep. 69 (1973); 38 SEC ANN. ReP. 70 (1972).

55. 280 U.S. 19 (1929).

56. Id. at 28. Cf. REA Express, Inc. v. CAB, 507 F.2d 42 (2d Cir. 1974) (use of similar 
A second consideration lies in the fact that if the SEC were to proceed as though it were the parens patriae of defrauded investors, defendants might then be in a better position to argue the applicability to the SEC's lawsuits of the hurdles that litigants in private actions must overcome in seeking a recovery. ${ }^{57}$ Courts in the past have dismissed the contention that the SEC is subject to the same obstacles on the ground that the Commission's interest is entirely different from that of the private litigant. ${ }^{58} \mathrm{~A}$ good example of the SEC's privileged position is found in SEC v. Petrofunds, Inc. ${ }^{59}$ where the defendants argued that the accounting and disgorgement of profits requested by the Commission in a suit for alleged fraud on investors in oil and gas drilling properties entitled the defendants to a trial by jury. The disgorgement of profits was identified with the relief that a private litigant might seek under the securities laws or in traditional common law actions. But the court dismissed this argument, saying that disgorgement when sought by the SEC is necessary to effectuate enforcement of the securities laws. ${ }^{60} \mathrm{~A}$ jury trial, therefore, was not required.

At present an SEC enforcement proceeding must satisfy only the bare statutory elements of proof: use of jurisdictional means; connection with a purchase or sale of a security; proof of a misrepresentation, misleading omission or other deception or manipulation; and the materiality of the misrepresentation or omission. ${ }^{61}$ The Commission may be reluctant to adopt a policy of actively representing defrauded investors if to do so might jeopardize this favored status of its enforcement actions in federal court.

names by competitive air carriers violates Federal Aviation Act of 1958 only to the extent that such use results in specific and substantial public confusion).

57. See United States v. Georgia Power Co., 474 F.2d 906, 923 (Sth Cir. 1973) (employment discrimination case brought by government on behalf of individuals in which the government was held to the same statute of limitations period applicable to individuals).

58. See Chris-Craft Industries, Inc. v. Piper Aircraft Corp., 480 F.2d 341, 391 (2d Cir.), cert. denied, 414 U.S. 910 (1973); SEC v. Manor Nursing Centers, Inc., 458 F.2d 1082, 1096 \& n.15 (2d Cir. 1972); SEC v. Quing N. Wong, 252 F. Supp. 608, 611 (D.P.R. 1966); S. REP. No. 74-75, 94th Cong., Ist Sess. 76 (1975), where it was said with respect to enactment of $\S 21(\mathrm{~g})$ of the 1934 Act, 15 U.S.C. \& 78u(g): "The Commission's basic point is that, although both the Commission's suit for injunctive relief brought pursuant to express statutory authority and a private action for damages fall within the general category of civil (as distinct from criminal) proceedings, their objectives are really very different. Private actions for damages seek to adjudicate a private controversy between citizens; the Commission's action for civil injunction is a vital part of the Congressionally mandated scheme of law enforcement in the securities area."

59. [1976-1977 Transfer Binder] FED. SEC. L. REP. (CCH) q 95,743 (S.D.N.Y. Oct. 13, 1976).

60. Id . at 90,605. See also SEC v. Penn Central Co., [1976-1977 Transfer Binder] Fed. SEC. L. REP. (CCH) I 95,867 (E.D. Pa. Dec. 28, 1976) (state statute of limitations and laches not applicable to SEC disgorgement action since suit was "not predominantly an action for restitution for the benefit of private parties." Id. at 91,192).

61. Cf. Blue Chip Stamps v. Manor Drug Stores, 421 U.S. 723 (1975) (private plaintiff must be purchaser or seller of securities in order to have standing to sue under rule 10b-5). But see SEC v. Bausch \& Lomb, Inc., 420 F. Supp. 1226, 1240-41 (S.D.N.Y. 1976) (SEC required to prove scienter in $10 \mathrm{~b}-5$ cases). 
Third, the Commission is ill-equipped to make whole persons who are injured by securities fraud. ${ }^{62}$ For one thing, there are obvious budgetary and manpower limitations. Even if the Commission were to decide to serve as the champion of injured investors it would find itself in the uncomfortable position of having to pick and choose between worthy causes in using its scarce resources. This is not a problem when it is acting chiefly for its own purposes. Finally, the SEC's recovery of defendants' profits, to the extent that there are any to be recovered, may not compensate injured investors for the damages they suffered, since the two amounts are not necessarily related. ${ }^{63}$

\section{Disgorgement Compared to Other Monetary Remedies}

Monetary restitution requires only that the fraudulent party relinquish the gains obtained through the fraud. ${ }^{64}$ Rescission and specific restitution, on the other hand, require that both parties be placed in the status quo ante as though the fraudulent transaction had never occurred. ${ }^{65}$ Under the latter concept the defrauded purchaser, who no longer wants to keep the security he has acquired, is entitled to receive back the money he paid the seller for it. The defrauded seller may receive back the security he sold, upon tendering the purchase price. ${ }^{66}$ Such a remedy is appropriate for a private litigant under the anti-fraud provisions of the federal securities laws only where he acts promptly to rescind upon discovery of the fraud. ${ }^{67}$ It is apparent that the amount obtained in a resitution of fraudulent gains may vary substantially from the value of what is received by specific restitution, and usually the two amounts will not be the same. ${ }^{68}$

62. See Herpich v. Wallace, 430 F.2d 792, 804 (5th Cir. 1970); Farrand, Ancillary Remedies in SEC Civil Enforcement Suits, 89 HARv. L. REv. 1779, 1802-03 (1976).

63. Dolgow v. Anderson, 43 F.R.D. 472, 483 (E.D.N.Y. 1968), rev'd on other grounds, 438 F.2d 825 (2d Cir. 1970).

64. Restatement OF RESTITUTION $\$ 150$ (1937). See D. DobBs, HANDBOoK ON THE LAW OF REMEDIES § 9.3 at 617 (1973); Note, Texas Gulf Sulphur: The Question of Remedy, 65 Nw. U.L. REV. 486, 490-91 (1970).

65. 3 J. POMEROY, TREATISE ON EquiTY JURISPRUDENCE $§ 910$ at 578 (5th ed. 1941).

66. Should the defendant in a private action be permitted to offset any tax benefits plaintiff obtained from his losses on the investment in determining what he owes the plaintiff when sued for rescission? At least one court has answered this question negatively. Cooper v. Hallgarten \& Co., 34 F.R.D. 482, 485-86 (S.D.N.Y. 1964).

67. Occidental Life Ins. Co. of N.C. v. Pat Ryan \& Assocs. Inc., 496 F.2d 1255, 1268 (4th Cir. 1974); Andrews v. Blue, 489 F.2d 367, 375-76 (10th Cir. 1973). See Reder, Measuring Buyer's Damages in 10b-5 Cases, 31 Bus. Law. 1839, 1843 (1976).

68. Where the two amounts are the same, it is possible for the SEC to have the same choice as a private litigant of either rescinding the transaction altogether with a re-exchange of the consideration received by both sides or allowing the transaction to stand and seeking only monetary restitution of the defendant's profits. See SEC v. Weisberger, [1974-1975 Transfer Binder] FED. SEC. L. REP. (CCH) I 95,108 at 97,943-44 (S.D.N.Y. June 3, 1975). Where the SEC seeks to require an offer of recission from the defendant, complications may arise, since the innocent investors may want to keep what they have and obtain their relief on some other 
A private litigant may also seek damages as compensation for securities fraud as an alternative to restitution. ${ }^{69}$ Damages are intended to "compensate [him] for the harm [he] suffered . . . as a result of the wrongful conduct, irrespective of the receipt of anything by the defendant. "70 Just as monetary restitution has the potential for differing greatly from specific restitution in the value of the recovery, so too may one's damage award vary greatly from the value of a recovery received in restitution. ${ }^{71}$

In most actions damages are computed on the basis of either of two theories: the "benefit of the bargain" or "out-of-pocket losses."72 However, it has been held that in cases of securities fraud the only appropriate damages are out-of-pocket losses. ${ }^{73} \mathrm{~A}$ recovery cannot include the anticipated but unrealized speculation that would be appropriate under a benefitof-the-bargain theory.

\section{LimITATIONS ON DisgorgemENT}

\section{A. No Penal Assessment}

There are limitations on the concept of disgorgement which have been averred to by the courts and the SEC, although they have not been particularly well delineated as yet. One such limitation mentioned in the Texas Gulf Sulphur litigation and subsequent decisions is that the remedy cannot be applied as a penal assessment. Under the securities laws the Commission can only recommend penal sanctions to the Attorney General; it cannot impose them itself. ${ }^{74}$ Moreover, it has been held that the Commission cannot impose its administrative remedies in a punitive fashion. ${ }^{75}$

The defendants in Texas Gulf Sulphur attempted in vain to convince the district court ${ }^{76}$ and the Court of Appeals for the Second Circuit ${ }^{77}$ that the

basis rather than accept an offer of rescission. See Chris-Craft Industries, Inc. v. Piper Aircraft Corp., 480 F.2d 341, 391 (2d Cir.), cert. denied, 414 U.S. 924 (1973).

69. A private litigant can, of course, recover his loss only once. 1934 Act $\$ 28$ (a), 15 U.S.C. $\S 78$ bb(a) (1970); 1933 Act $\S$ I2, 15 U.S.C. $\S 771$ (1970).

70. RESTATEMENT OF RESTITUTION, supra note 64 , ch. 7, Introductory Note at 522-23; see Haines v. St. Paul Fire \& Marine Ins. Co., 428 F. Supp. 435, 441 (D. Md. 1977).

71. See Affiliated Ute Citizens v. United States, 406 U.S. 128, 155 (1972).

72. Note, supra note 64, at 495. See generally Annot., 13 A.L.R.3d 875 (1967).

73. Wolf v. Frank, 477 F.2d 467, 478 (5th Cir.), cert. denied, 414 U.S. 975 (1973); Richardson v. MacArthur, 451 F.2d 35, 43 (10th Cir. 1971). See 3 A. Bromberg, Securities Law: FRAUD \$ 9.1 at $226 \mathrm{nn} .2 \& 3,227$ n.4 (1971).

74. 1933 Act $\S 20($ b), 15 U.S.C. $\$ 77 t$ (b) (1970); 1934 Act $\$ 21(d), 15$ U.S.C.A. $\S 78 u(d)$ (West Supp. 1976).

75. Beck v. SEC, 430 F.2d 673, 674 (6th Cir. 1970) (SEC suspension of a broker reversed as punitive).

Punitive damages are not authorized in private actions under the 1933 and 1934 Acts. Hill York Corp. v. American International Franchises, Inc., 448 F.2d 680, 697 (5th Cir. 1971) (1933 Act violations); Green v. Wolf Corp., 406 F.2d 291, 302-03 (2d Cir. 1968), cert. denied, 393 U.S. 977 (1969) (10b-5 context).

76. 312 F. Supp. at $92-93$.

77. 446 F.2d at 1308. 
restitution payments they would be required to make would be punitive and therefore contrary both to the intent of Congress and the spirit of equity. In response, both courts stressed that the restitution of profits merely deprived the defendants of the gains derived from their wrongful conduct, a perfectly appropriate remedy. ${ }^{78}$ In addition, the court of appeals justified the payments as compensatory rather than punitive on the ground that the Texas Gulf Sulphur Company itself may have suffered harm to its corporate goodwill and the public's regard for its securities as a result of insiders abusing their corporate positions. Hence, the payments were made on a contingent basis to the company as compensation for the damage it had suffered. ${ }^{79}$ The difficulty with this analysis is that it cannot be used in the relatively common situation of insiders who fraudulently trade in the stock of a corporation which is controlled by them, even though the corporate goodwill may have in fact suffered because of the fraudulent trading. Any court-ordered attempt to restore the economic loss caused to the corporate goodwill in such a situation would merely redound to the principal benefit of the wrongdoing shareholders.

With regard to restitution of the gains made by tippees, the Commission explained the need to hold the tipper liable for those profits without attempting to rationalize a compensatory ground for the remedy. It maintained that since the tippers had made possible the profits of the persons to whom they divulged inside information, presumably the tippers had received certain intangible benefits by this conduct. If disgorgement stopped with the tipper's profits, then the remedy would be undermined because the tipper would still be encouraged to authorize others to do what he was forbidden to do himself. ${ }^{80}$ The Second Circuit agreed with this analysis. ${ }^{81}$

The penal effect of the disgorgement relief was again raised before the Second Circuit in SEC v. Manor Nursing Centers, Inc. ${ }^{82}$ In that case, shares in a nursing home were sold to the public under an "all-or-nothing", registered offering-all funds received would be returned if any shares remained unsold after a specified date. Through various contrived and false transactions, Manor and its principals were able to make it appear that the entire offering had been sold out prior to the offering period deadline.

78. Id.; 312 F. Supp. at 93.

79. 446 F.2d at 1308.

80. SEC Pretrial Memorandum of Law, supra note 1, at 54-55. The Commission's Pretrial Memorandum cited Mosser v. Darrow, 341 U.S. 267 (1951), where a reorganization trustee had allowed two of his employees to trade in securities of subsidiary companies under his control. The Court there said the sanctions against the trustee were necessary since otherwise the strict prohibition against a trustee trading in the securities of a debtor would serve little purpose; the trustee would be free to authorize others to do what he was forbidden. Id. at 271-72.

81. 446 F.2d at 1308.

82. 458 F.2d 1082 (2d Cir. 1972). 
Manor, its principals and others then took substantial financial benefits from the fraudulent offering which the SEC sought to have disgorged.

The lower court complied with the Commission's request. ${ }^{83}$ It ordered a disgorgement of the proceeds received in connection with the offering ${ }^{84}$ and also all the profits and income earned on those proceeds. The court of appeals generally approved of the disgorgement, but could not accept the portion of the lower court's order which required the return of profits on the profits, finding that part to constitute a penalty assessment. The appellate court admitted that the deterrent effect might be enhanced if profits on profits were also disgorged. But it concluded that there was already sufficient deterrence in the disgorgement of the underlying profits, that it was arbitrary to assess more from defendants who had profitably invested their illegal gains than from those who had not, and that private litigants would not be allowed to obtain the recovery of such secondary profits. ${ }^{85}$

Having come to this conclusion in Manor Nursing, the Second Circuit suggested a somewhat different result several years later in Zeller v. Bogue Electric Manufacturing Corp. ${ }^{86}$ a private securities fraud action. There, in a footnote, the court stated that "it seems appropriate to require the seller to disgorge any profits he would not otherwise have been in a position to realize if these can be traced with sufficient certainty." 87 The court made no reference to its decision in Manor Nursing that subsequent profits which were perfectly traceable ought not to be disgorged, even though the wrongdoers had earned them as a result of their fraudulent activities.

One distinction which may have influenced the court is that Manor Nursing was an SEC enforcement action whereas Zeller was not. Perhaps the court felt more kindly disposed toward recovery by private litigants than by the SEC. Another possible ground for reconciling these two positions lies in the distinction between profits on profits which are "earned" by the defendant, as compared to such profits that are perceived to be merely a windfall to the defendant. Disgorgement of earnings may not be considered appropriate, but disgorgement of windfall profits may be appropriate for several reasons. First, as between the wrongdoing party and the innocent

83. 340 F. Supp. 913 (S.D.N.Y. 1971).

84. The facts recited in the lower court's opinion suggest that the actual out-of-pocket expenses of some $\$ 145,000$ incurred in making the of fering (which excludes the $\$ 450,000$ in selling commissions promised the defendant underwriter and the broker-dealer selling group) were largely satisfied by the creditors agreeing to take some $\$ 142,000$ worth of Manor stock from the offering. Id. at 923,928 . Assuming this to be the case, the lower court's order that the defendants account for all of the cash proceeds they received through the offering is the equivalent of ordering an accounting for their fraudulent profits, since the cash proceeds received from the offering were net of expenses.

85. $458 \mathrm{~F} .2 \mathrm{~d}$ at $1104-05$.

86. 476 F.2d 795 (2d Cir.), cert. denied, 414 U.S. 908 (1973).

87. 476 F.2d at 802 n. 10 . 
party, any unexpected gains connected with the wrongful transaction ought to go to the latter. Second, had the fraud not occurred, the windfall might reasonably be expected to have come to the innocent party, at least where the fraud was committed by a buyer. ${ }^{88}$

The distinction between earned and unearned profits on profits seems to have been expressed more keenly in Janigan $v$. Taylor ${ }^{89}$ In that case the president of a company bought out the stockholders on the basis of statements that violated rule $10 \mathrm{~b}-5$. The price was $\$ 40,000$. Less than two years later the president sold his stock for $\$ 700,000$. The court held that the former shareholders were entitled to recover the full gain as unjust enrichment, even though there was no assurance that, had the stock not been sold, the plaintiffs could have done as well as they did. The court felt that the profits gained were not caused by the special efforts of the president. Had they been, the court implied that it would have measured the amount of recovery differently. "If an artist acquired paints by fraud and used them in producing a valuable portrait we would not suggest that the defrauded party would be entitled to the portrait, or to the proceeds of its sale." 90

A similar type of case is Brooks v. Conston. ${ }^{91}$ The defendant in Brooks fraudulently acquired plaintiff's chain of retail stores. The profits from the stores were used to open new stores and to purchase other assets. Upon proving the fraud, the plaintiff was allowed to recover everything that the defendant had amassed since the original sale, including all the business' profits and all of its added assets, minus a sum representing the reasonable value of defendant's services as a manager to the business during the time he held it. The court felt that it was appropriate to allow a deduction for defendant's services since the assets which he had fraudulently acquired were enhanced by the fruits of his management. ${ }^{92}$

The Janigan and Brooks cases raise the difficult question of how one should value economically the input of a defendant in managing the fraudulent gains, if his skills and efforts are to be granted any weight at all as far as creating profit on profit. Perhaps this problem may be more an academic than real one, however, since courts are likely to be more influenced by the overall equitable positions of the parties than by some economic formula. In any event this determination is an equitable one and therefore not subject to challenge for any lack of scientific accuracy.

The Second Circuit appears to have applied its Manor Nursing position of non-recovery of secondary profits to a case involving secondary losses on

88. Cf. Affiliated Ute Citizens v. United States, 406 U.S. 128, 155 (1972) (where defendant's profit exceeds plaintiff's actual loss, the damages are the former).

89. 344 F.2d 781 (1st Cir.), cert. denied, 382 U.S. 879 (1965).

90. Id. at 787 .

91. $364 \mathrm{~Pa} .256,72$ A.2d 75 (1950).

92. Id. at $262-74,72 \mathrm{~A} .2 \mathrm{~d}$ at 79. 
the ill-gotten gains. In $S E C$ v. Shapiro, ${ }^{93}$ the defendant continued to hold stock he had fraudulently obtained after the inside information on which he had acquired the stock became public. The district court ordered the defendant to disgorge his profits computed as of the day the inside information was publicly disclosed..$^{94}$ The defendant argued that such a disgorgement constituted a penalty because he would be forced to give up more than the stock was actually worth when it was sold, as its value had dropped after the inside information became public. The Court of Appeals disagreed with defendant's logic, noting that:

[Defendant's] additional losses resulted not from any penalty imposed by the court but from his unwise investment decision to keep the stock after February 18 [the date the inside information became public].

[A] contrary holding would create a serious anomaly that might encourage insider trading. To require disgorgement only of actual profits in cases where the price of the stock subsequently fell would create a heads-I-win-tails-you-lose opportunity for the violator: he could keep subsequent profits but not suffer subsequent losses. ${ }^{95}$

\section{B. Deducting for Defendant's Costs and Expenses}

Can it be argued in an SEC disgorgement action that the defendant is in effect penalized unless all of his costs and expenses incurred in connection with the challenged transaction are properly taken into account in computing his "profit"? The Restatement of Restitution does recogmize that in making restitution following a fraudulent transaction, the defendant is entitled to reimbursement or to an offset for sums he paid to maintain the fraudulently obtained property, but not to alter it to suit his personal wishes. ${ }^{96}$ Thus, $A$ who induces $B$ by fraud to convey Blackacre to him is entitled, upon returning Blackacre to $B$, to the purchase price and to be reimbursed for mortgage, tax and repair payments made by him while he held the property, but not for the cost of painting it a different color. Suppose a buyer acquires through fraud a security, such as a limited partnership interest, where certain additional future payments are required from the holder of that security. If the defrauded party later rescinds the transaction and obtains specific restitu-

93. 494 F.2d 1301 (2d Cir. 1974).

94. Id. at 1309.

95. Id. Note that the court's coin-toss characterization in Shapiro suggests that it had not abandoned its position stated in Manor Nursing that a wrongdoer who profitably invests his illgotten gains should not have to disgorge his secondary profits, too.

In SEC v. Blatt, [1975-1976 Transfer Binder] FED. SEC. L. REP. (CCH) ๆ 95,281 (S.D. Fla July 24, 1975), the court recognized that it could require a disgorgement of "paper profits" as well as actual profits, citing Shapiro, but concluded that it would be inappropriate to do so in that case. $I d$. at 98,444 .

96. RestatemENT OF RestituTion, supra note 64 , at $\S 158$, Comments a-d. 
tion of his partnership interest, the principles in the Restatement would appear to apply so that the fraudulent buyer must be reimbursed for any additional payments made by him while holding the interest. However, if the SEC were to obtain monetary restitution from the fraudulent buyer the same principle would not appear to apply. The SEC is entitled to the profit made on the fraudulent transaction; a subsequent payment by the purchaser incident to his ownership of the interest does not affect that profit, even though it will affect the overall yield on defendant's improper investment.

A more typical possible deduction for the defendant who must disgorge concerns the costs and expenses incurred by him in connection with selling or purchasing the securities involved. Certain provisions of the Trademark Act of $1946^{97}$ bear considerable analogy to the disgorgement context. In enacting this legislation, Congress determined that one way to protect trademarks was by "making infringement and piracy unprofitable." 98 Thus, section 35 of that Act grants to plaintiffs the right to recover defendant's profits. ${ }^{99}$ Significantly, while Congress has seen fit to provide for the recovery of "profits" as a deterrent against infringement, it has also provided that the defendant is entitled to set off against his sales figures for the infringing product all proven costs or deductions. ${ }^{100}$ The statute does not define what constitutes a "cost or deduction" for this purpose, thus leaving that question to be resolved by the accountants and the courts.

Cases under the Trademark Act offer some instruction as to which costs and expenses are appropriate to consider in computing a disgorgement sum. In Aladdin Manufacturing Co. v. Mantle Lamp Co. of America, ${ }^{101}$ the infringer's conduct was found to be fraudulent and willful in perpetrating the infringement and in deceiving the public with blatantly false advertising. Despite this lack of equity in the defendant's favor, the court took a broad view of what were the appropriate deductions from defendant's gross profit. It stated: "Even though the methods employed in realizing gain were not proper, yet they were part of the costs of realization from sales from which profits resulted. Awarding to appellant profits necessitates the deduction of the cost of realization thereof." 102

In applying this rationale a court could justify the non-deductibility of fixed costs, for example, on the ground that such costs would have been incurred even if the infringer had not made the infringing product, provided it was producing other goods as well. By the same token, the rule expressed

97. 15 U.S.C. $\$ \S 1051-1127$ (1970).

98. S. ReP. No. 1333, 79th Cong., 2d Sess. 3 (1946). See Monsanto Chem. Co. v. Perfect Fit Prods. Mfg. Co., 349 F.2d 389 (2d Cir. 1965).

99. 15 U.S.C.A. \& 1117 (West Supp. 1976).

100. Id.

101. 116 F.2d 708 (7th Cir. 1941).

102. Id. at 714. See W.E. Bassett Co. v. Revlon, Inc., 435 F.2d 656, 665 (2d Cir. 1970). 
in Aladdin resulted in allowing the deduction of the salary defendant had paid its principal officer, even though he was the dominant force responsible for the defendant's wrongful infringement. In explaining this result, the court said:

[W]e are not dealing now with punitive damages but rather with actual profits. The amount deducted as salary was actually paid [the officer] for the management and conduct of the business and in determining the actual profits for which appellee should account, we must credit all costs. Salaries paid to officers are proper deductions. ${ }^{103}$

The SEC has, at least in some instances, reduced or even eliminated disgorgement claims when confronted with the defendant's costs relating to the questioned transactions. ${ }^{104}$ Depending on the type of security involved, these costs may be quite significant in securities fraud cases. A real estate developer, for example, may solicit hundreds of thousands of dollars in the sale of limited partnership interests to investors. Most of the money is usually spent on acquisition and development costs, sales and real estate commissions, legal fees and so forth. If all those items go to outsiders, the developer's "profits" will be only a small fraction of the proceeds which he received at the outset. Furthermore, if the developer or his company becomes a general partner in the limited partnership, he may incur additional liabilities which can affect over the long term the true profit, if any, he derives from sale of the partnership interests. As another example, a securities broker-dealer will have sales commissions, administrative costs, telephone charges and so on, in addition to the acquisition cost of the security itself, all of which could substantially reduce the "profit" on the purchase or sale of a security. In both instances, it would appear that the principles of equity ought to permit the defendant to offset all of his expenditures against the gross proceeds he received from the challenged transaction in computing his profit. ${ }^{105}$

103. 116 F.2d at 713. Contra, Wolfe v. National Lead Co., 272 F.2d 867, 873 (9th Cir. 1959); Champion Spark Plug Co. v. Sanders, 108 F. Supp. 674, 678-79 (E.D.N.Y. 1952), aff'd per curiam, 204 F.2d 125 (2d Cir. 1953). See Callaghan v. Myers, 128 U.S. 617, 664 (1888) (no deduction allowed for defendant's services while engaged in violating the rights of the plaintiff).

104. See SEC v. Continental Silver Corp., SEC Litigation Release No. 6993 (Aug. 6, 1975), 7 SEC DoCKET 534 (1975); SEC v. Continental Silver Corp., SEC Litigation Release No. 7033 (July 18, 1975), 7 SEC DoCKET 448 (1975) (Commission staff agreed to dismiss portion of complaint against defendants charged with violations of antifraud provisions in offer and sale of silver investments agreements "in view of accounting furnished to the Court" by the defendants); SEC v. American Commodity Exchange, SEC Litigation Release No. 6931 (June 12, 1975), 7 SEC DOCKET 177 (1975) (disgorgement sought only of funds received from public which were not used for the purchase of commodity option contracts as promised); SEC v. Starr, SEC Litigation Release No. 6718 (Feb. 7, 1975), 6 SEC DoCKET 275 (1975) (defendant charged with fraud in offer and sale of oil and gas limited partnerships ordered to disgorge only those amounts of money not applied as promised to investors).

105. See M. Ehrich, The LAw of Promoters $\$ 266$ at 484 (1916): "A promoter should, on accounting for his secret profits, be allowed credit for his legitimate expenses on the promotion." 
Even when a court recognizes that defendants who are liable to disgorge are entitled to deduct their related costs, difficult questions may nevertheless remain in reaching an appropriate disgorgement sum. An example is SEC v. Commonwealth Chemical Securities, Inc. ${ }^{106}$ There the court was confronted with four different ways to compute defendants' costs, each a substantial monetary amount apart from the others. The defendants had violated the federal securities laws in connection with their trading in the securities of Beneficial Labs, Inc. from December 20, 1971 through March 2, 1973. The SEC proposed two methods of calculating the profits to be disgorged which employed the "first in-first out" (FIFO) accounting concept by matching the purchase price paid for the first purchase against the sale price of the first sale in each of the defendants' controlled accounts. The SEC's "Method I' modified pure FIFO treatment in several respects, however. If a purchase and sale took place the same day for the same amount of securities, those two transactions were directly paired. Also, if the number of securities sold in an account exceeded the number purchased, Method I transferred an appropriate number of securities from other accounts controlled by the defendant in order to fix a price basis for computing the profits on those excess sales. The SEC's Method II differed from Method I only to the extent of ignoring the excess sales. Under Method II no securities were transferred between accounts in making the calculations. ${ }^{107}$

The defendants, on the other hand, proposed "last in-first out"' (LIFO) treatment as Method III for computing the profits. In a rising market for Beneficial's securities this method had the effect of generally reducing profits on the individual defendant's trading by attributing a higher cost for the securities traded than under the FIFO method. The defendants also proposed a Method IV which ignored any transactions in Beneficial's securities that were solely between the defendants on the ground that these transactions did not adversely affect the public. Thus, under this last method the total purchase price on purchases from the public was subtracted from the total sales price on sales to the public to arrive at a net figure deemed to be the defendant's profits. ${ }^{108}$

The court found basic flaws in three of the four methods presented to it. Method I was objectionable because there was no evidence that the defendants had actually transferred securities between accounts. Method III unrealistically inflated defendants' purchase prices. Method IV had the effect of allocating most of the profit to the corporate defendant, a broker-dealer, since most of the sales to the public were made from its trading account. The

106. [1976-1977 Transfer Binder] Fed. SEC. L. REP. (CCH) I 95,741 (S.D.N.Y. Sept. 29, 1976).

107. Id. at $90,596$.

108. Id. 
court suspected that this defendant was judgment-proof. It therefore concluded that Method II achieved the most equitable result, although it recognized that such an assessment was only a "reasonable estimate based on the evidence." 109

\section{Income Taxes on Fraudulent Profits}

Besides costs incurred in earning the profits at issue, a defendant also will have incurred a liability for income taxes, ${ }^{110}$ the payment of which will further reduce his ultimate gain on the transaction. A leading case on the question of the deductibility of income taxes in figuring profits on a trademark infringement is L.P. Larson, Jr., Co. v. William Wrigley, Jr., Co. . ${ }^{111}$ In that case, Mr. Justice Holmes, writing for the Court, recognized that there may be cases in which such a deduction would be proper but that it was inequitable to do so when the infringement constituted a conscious and deliberate wrongdoing. ${ }^{12}$ A similar position was taken in Wolfe v. National Lead Co. ${ }^{113}$ where it was said that income taxes, in the absence of mitigating circumstances, were not proper deductions. ${ }^{114} \mathrm{~A}$ contrary position was taken in W.E. Bassett Co. v. Revlon, Inc. ${ }^{115}$ without discussion or authority, even though the court acknowledged that the infringement was willful.

One could argue that the Larson rule should not apply to SEC disgorgement cases on the ground that the same equitable considerations are not present. ${ }^{116}$ In Larson, Justice Holmes considered the fact that the victim of the infringement would have to pay income taxes of its own on any profits received by it from the infringer. The Court thought it inequitable, given the respective tax burdens, to grant a deduction to the infringer, thereby further reducing the after-tax profits received by the injured party.

In an SEC disgorgement case, the specific interests, tax or otherwise, of the injured investors are disavowed by the Commission; its primary interest is to make securities fraud unprofitable. ${ }^{117}$ Therefore, the tax effect on private investors ought not to be a factor to be taken into account in weighing the respective equities. The situation is different for the defendant.

109. Id. at $90,597$.

110. See James v. United States, 366 U.S. 213 (1961).

111. 277 U.S. 97 (1928).

112. Id. at $99-100$.

113. 272 F.2d 867 (9th Cir. 1959).

114. Id. at 873.

115. 435 F.2d 656 (2d Cir. 1970). See D. DoBBs, supra note 64, at $\S 4.5$.

116. In Cathedral Estates, Inc. v. Taft Realty Corp., 251 F.2d 340 (2d Cir. 1957), a stockholders' derivative action, the principal asset of the corporation, a hotel, was wrongfully conveyed to another corporation. Defendants sought credit for federal and state income taxes in an accounting in plaintiff's securities fraud action. The court simply held that the Larson rule required "innocent wrongdoing," and the credit was denied. Id. at 341.

117. See text accompanying notes 50-54 supra. 
To the extent that he must disgorge pre-tax profits using after-tax dollars, he has obviously been deprived of not only his gains, but also the amount of the $\operatorname{tax}$ on those gains. It seems, therefore, that the tax effect on him ought to be considered.

The fact that the defendant may be entitled to claim a loss deduction equal to the amount of his disgorged payment ${ }^{118}$ does not necessarily insure that he will not incur a tax disadvantage. If he pays the tax on the questioned profits in the first year and then must take his loss deduction in a later tax year when he makes restitution of those profits, ${ }^{119}$ it is unlikely that the tax liability and subsequent deduction will actually cancel one another. The defendant's ultimate tax bill depends on a variety of largely unpredictable factors, including his other income and deductions in the tax years in question and whether the same costs and expenses are used in figuring the disgorgement amount as in figuring the taxable profits.

Rather than leave to mere happenstance the possible imposition of unfavorable tax consequences, which in such circumstances would penalize the defendant as a result of his disgorgement payment, it seems that greater equity could be achieved by deducting at the outset the tax the defendant paid on the challenged profits from the figure to be disgorged. In this way the defendant would be assured of receiving full credit for his taxes on income he was not allowed to keep, but credit for no more than that amount. This approach would further require that the defendant either agree or be ordered not to claim a tax deduction as to the adjusted disgorgement sum, since otherwise he would be afforded a double deduction.

\section{Effect of Adverse Publicity}

There is no question but that the publicity surrounding SEC charges of securities fraud will also have to a certain extent a "cost" effect upon any target of those charges. This fact has been recognized by courts, ${ }^{120}$ commentators $^{121}$ and the securities bar. ${ }^{122}$ In a given situation it may appear that the

118. See James v. United States, 366 U.S. 213, 220 (1961); Rev. Rul. 65-254, 1965-2 Cum. BuLl. 50 (restitution of embezzled funds by embezzler permits him to take a loss deduction from adjusted gross income); Rev. Rul. 61-115, 1961-1 CuM. BuLL. 46 (allowance of a tax deduction for restitution paid by reason of section 16(b) of the 1934 Act does not frustrate public policy).

119. See United States v. Lewis, 340 U.S. 590 (1951).

120. SEC v. Texas Gulf Sulphur Co., 312 F. Supp. 77, 90 (S.D.N.Y. 1970); see Silver King Mines, Inc. v. Cohen, 261 F. Supp. 666, 674-75 (D. Utah 1966). See also FTC v. Cinderella Career and Finishing Schools, Inc., 404 F.2d 1308 (D.C. Cir. 1968).

121. Freedman, A Civil Libertarian Looks at Securities Regulation, 35 Оноо ST. L.J. 280, 284-85 (1974); Gellhorn, Adverse Publicity by Administrative Agencies, 86 HARv. L. Rev. 1380, 1394-98 (1973).

122. In 1964 the House of Delegates of the American Bar Association recommended that all disciplinary proceedings before the SEC be private unless the Commission determines, after allowing respondent a private hearing, that investor protection requires a public hearing. 89 
monetary effect of adverse publicity deserves to be taken into account in fashioning an equitable disgorgement figure.

Publicity was taken into account in determining the appropriate remedial outcome in In re Provident Management Corp. ${ }^{123}$ That case involved violations by certain investment advisors of section $10 \mathrm{~b}$, rule $10 \mathrm{~b}-5$ and section 17(a), among others, for having received improper payments from brokers while acting as investment advisers to a mutual fund. The respondents' settlement offer, which included the disgorgement of certain of their profits, was accepted by the Commission partly because it took into account the adverse publicity caused by bringing its action against the respondents. ${ }^{124}$ In Texas Gulf Sulphur, the district court also acknowledged the adverse publicity suffered by the defendants and the deterrent effect it would have in the course of reviewing the disgorgement relief that was sought. However, the court did not moderate the relief granted because of this publicity. ${ }^{125}$ Courts have, on the other hand, often recognized the harmful impact of an injunction on the defendants' personal reputation and legitimate business activities, ${ }^{126}$ and in some cases that form of relief has been denied as a consequence of giving consideration to this factor. ${ }^{127}$ There appears to be no reason why such equitable considerations ought not to apply as well when disgorgement relief is sought by the SEC.

\section{E. Other Considerations}

There are a variety of other factors which may in certain circumstances limit the SEC's efforts at disgorgement. For instance, its success may be inhibited by what could be accomplished by a litigant in a private lawsuit. $A$ private litigant cannot recover damages or restitution for fraud where there is no resulting pecuniary loss. ${ }^{128}$ Since the SEC is concerned with deterring fraudulent activities by depriving the wrongdoer of the monetary incentive to commit securities fraud, the fact that private litigants could not recover

REP. A.B.A. 135 (1964). See generally ABA Advisory COMM. ON ENFORCEMENT POLICIES AND PRACTICES, REPORT OF THE Advisory COMM. ON ENFORCEMENT POLICIES AND PRACTICES (1972).

123. SEC Securities Act of 1933 Release No. 5115 (Dec. 1, 1970), [1970-1971 Transfer Binder] FED. SEC. L. REP. (CCH) $\llbracket 77,937$.

124. Id. at 80,089-90.

125. $312 \mathrm{~F}$. Supp. at 90 . The court did recognize that publicity alone might serve as an adequate deterrent when the violation was a "once-in-a-lifetime affair," and on those grounds the court could decline to issue an injunctive order against the company. Id.

126. See, e.g., SEC v. Manor Nursing Centers, Inc., 458 F.2d 1082, 1102 (2d Cir. 1972); SEC v. Broadwall Securities, Inc., 240 F. Supp. 962, 967 (S.D.N.Y. 1965).

127. See, e.g., SEC v. Pearson, 416 F.2d 1339, 1343 (10th Cir. 1970); SEC v. Harwyn Industries Corp., 326 F. Supp. 943, 957-58 (S.D.N.Y. 1971); SEC v. International CamraCorder Corp., [1964-1966 Transfer Binder] FED. SEC. L. REP. (CCH) ๆ 91,666 (S.D.N.Y. Apr. $1,1966)$ (all denying injunctive relief).

128. See Fershtman v. Schectman, 450 F.2d 1357 (2d Cir. 1971), cert. denied, 405 U.S. 1066 (1972); Levin v. Seilon, Inc., 439 F.2d 328 (2d Cir. 1971). See generally Restatement of RESTITUTION, supra note 64 , at $\S 28$, Comment d at $126 ; 3$ J. POMEROY, supra note 65 , at $\S 898$. 
should be of no moment. Nevertheless, a court of equity looking at the SEC's disgorgement claim is likely to be influenced by the fact that no one was injured, even though there may have been technical violations of the law. Even more unfavorable for the SEC is the fact that any disgorged amount would have to be distributed to the investors who were not harmed. The court in Manor Nursing Centers, for example, was unwilling to carry the disgorgement remedy as far as the SEC wanted it to go, partly because the court thought it "significant" that private litigants could not obtain a similar recovery. ${ }^{129}$ Thus, if one could successfully demonstrate that in fact none of the investors had either lost money or been deprived of an opportunity that was rightfully theirs, a strong equitable argument could be made that the SEC had no business suing for disgorgement.

Economics may also limit the Commission's freedom to bring actions for disgorgement. Obviously, its finite resources cannot withstand a universal application of the disgorgement concept. The Commission may be content in a particular case to leave to private litigants the task of obtaining a monetary recovery and thereby deterring harmful conduct in the future. ${ }^{130} \mathrm{It}$ may negotiate a settlement with the defendant whereby he agrees to waive or toll, for a specific period and in lieu of disgorgement, the applicable statute of limitations, thereby aiding and encouraging private investors to assert their rights against the defendant. ${ }^{131}$ It may also require the defendant to

129. 458 F.2d at 1104.

130. In SEC v. Lum's, Inc., 365 F. Supp. 1046 (S.D.N.Y. 1973), the Commission brought an action to enjoin certain defendants from future violations with respect to their insider trading. At least one of the defendants, Investors Diversified Services, Inc. (IDS), was able to avoid incurring a substantial loss because of the inside information it received. The SEC's action did not seek a recovery of that "benefit" to IDS. IDS merely entered into a stipulation with the SEC whereby it consented to the entry of a permanent injunction against such violations in the future. Id. at 1065. However, IDS was also sued in private actions both inside and outside the federal securities laws arising from the same facts. See, e.g., Gildenhorn v. Lum's, Inc., 335 F. Supp. 329 (S.D.N.Y. 1971), rev'd sub nom. Schein v. Chasen, 478 F.2d 817 (2d Cir. 1973), vacated sub. nom. Lehman Brothers v. Schein, 416 U.S. 386 (1974) (reversed by circuit court in favor of stockholders, vacated by Supreme Court and remanded for consideration of state law) (alleging that IDS conspired with corporate officers to misuse corporate information). See also S. Rep. No. 94-75, supra note 58, at 74: "Private litigants will frequently file actions, the allegations of which closely follow those of the Commission's action, and there are. of ten attempts to 'ride along on the Government's cases.' "'

In SEC v. Lum's, Inc., SEC Litigation Release No. 6922 (June 6, 1975), 7 SEC DOCKET 173 (1975) and SEC v. Lum's, Inc., SEC Litigation Release No. 5238 (Dec. 6 1971), the complaint alleged false and misleading proxy and registration statements made in connection with the acquisition of a hotel. As part of the ancillary relief requested by the SEC, the defendants contributed $\$ 1.1$ million in cash towards an overall settlement of private actions which were based on allegations similar to those in the Commission's complaint.

131. See, e.g., SEC v. Milton, SEC Litigation Release No. 3796 (Aug. 30, 1967). See also SEC v. Nelson, SEC Litigation Release No. 7347 (Apr. 12, 1976), 9 SEC DocKET 441, 442 (1976) (defendant agreed to appoint agents for service in New York state and federal courts for 180 day period and not to contest the jurisdiction of any private suits therein. The SEC did not seek disgorgement). 
appoint a receiver or special counsel who will investigate potential private causes of action and sue on behalf of the innocent parties wherever appropriate. ${ }^{132}$ The necessary deterrence is achieved through deprivation of any gains at little cost to the SEC's limited resources.

Finally, the Supreme Court in Ernst \& Ernst v. Hochfelder ${ }^{133}$ has now held that a private right of action for damages will not lie under section 10(b) of the 1934 Act and rule 10b-5 in the absence of an intent to deceive, manipulate or defraud. Because the Ernst \& Ernst case involved an action for damages, the Court chose not to consider the question of whether a wrongful intent or "scienter" is a necessary element in an action for injunctive relief under section 10 (b) and rule $10 \mathrm{~b}-5 .{ }^{134}$ But one lower court, relying on Ernst \& Ernst, has held that scienter is a necessary element even in an injunctive action brought by the SEC. ${ }^{135}$ If this decision is upheld, the Commission's disgorgement remedy, which is necessarily dependent upon injunctive action, will be similarly restricted to instances where scienter is present. The practical effect of such a result may not be as significant as one might expect, however, since supposedly the Commission's limited resources have always forced it to focus its attention for purposes of disgorgement on willful fraud. ${ }^{136}$

\section{EXPANSION OF THE DISGORGEMENT CONCEPT}

\section{A. Equitable Considerations}

Just as the Commission's disgorgement relief can be limited by special factors, so also can special factors expand its applicability beyond the conceptual limits. This is particularly true in the context of equity, where "remedies are a special blend of what is necessary, what is fair and what is

132. See, e.g., SEC v. Generics Corp. of America, SEC Litigation Release No. 7218 (Dec. 29, 1975), 8 SEC DockET 951 (1976); SEC v. Eastern Freight Ways, Inc., SEC Litigation Release No. 7171 (Nov. 19, 1975), 8 SEC DockET 517 (1975). See also SEC v. J.L. Mead \& Co., SEC Litigation Release No. 7162 (Nov. 13, 1975), 8 SEC DockET 431 (1975).

133. 425 U.S. 185 (1976).

134. Id. at 193 n.12. However, Justice Powell's sweeping pronouncement at the end of his opinion for the majority in Ernst \& Ernst would seem to foreshadow the SEC's fate in this regard:

When a statute [\$10(b) of the 1934 Act] speaks so specifically in terms of manipulation and deception, and of implementing devices and contrivances-the commonly understood terminology of intentional wrongdoing - and when its history reflects no more expansive intent, we are quite unwilling to expand the scope of the statute to negligent conduct.

Id. at 214 .

135. SEC v. Bausch \& Lomb, Inc., 420 F. Supp. 1226, 1240-41 (S.D.N.Y. 1976). Contra, SEC v. World Radio Mission, Inc., 544 F.2d 535, 540-41 (1st Cir. 1976) (intent to deceive not required in SEC enforcement action despite Ernst \& Ernst).

136. But see Chris-Craft Industries, Inc. v. Piper Aircraft Corp., 480 F.2d 341 (2d Cir.), cert. denied, 414 U.S. 924 (1973) (rescission sought despite fact that fraud violations appeared to be technical and not perpetrated in bad faith). 
workable." 137 The case of SEC v. R.J. Allen \& Associates, Inc. ${ }^{138}$ represents an example of egregiously fraudulent conduct on the part of the defendants which led the court to order disgorgement of all proceeds received in the fraudulent transactions. R.J. Allen \& Associates was a Florida broker-dealer which engaged, as a part of its business, in the offer, sale and underwriting of so-called Industrial Development Revenue Bonds (IDRs). These bonds are considered municipal bonds, but are dependent upon the revenue of the company funded by the proceeds; they are not backed by any state or local taxing authority, although their interest payments are tax-exempt to the investor. ${ }^{139}$

The evidence demonstrated that the defendants engaged in a course of conduct designed to deceive and defraud investors by making false and misleading statements about the guaranteed nature of the bonds and by omitting information that should have been revealed about their real risk. The defendants also delivered bonds other than those the investors had purchased, and in some instances failed to execute a purchase transaction after having received a customer's funds for a purchase. As part of their scheme, defendants solicited former prisoners of the Vietnam war who had accumulated substantial sums of back pay. The correspondence from the defendants offered to invest the ex-POWS' assets in securities sold at R.J. Allen, particularly the high risk, speculative IDRs which were palmed off as safe, secure, liquid investments. ${ }^{140}$ Once the truth was discovered, the court found that many of the investors had been "left destitute" as a consequence of the "vicious and brutal" frauds committed by defendants. ${ }^{141}$

Given this factual setting, the court readily ordered an accounting, but not merely for the purpose of determining the defendants' profits. The accounting was to ascertain the full amount of the proceeds received by the defendants as a result of the sales of IDRs. The court then discussed "disgorgement," noting that the concept sought to deprive defendants of the gains of their wrongful conduct. However, while making a reference to wrongful gains, the court went much further in granting the SEC's request for relief: "In dealing with plaintiff's prayer for disgorgement, this Court equates disgorgement with restitution and recoupment which are equity remedies of ancient origin." 142 The defendants were ordered to restore to the court-appointed receiver the full amounts obtained from all the investors

137. Lemon v. Kurtzman, 411 U.S. 192, 200 (1973) (footnotes omitted).

138. 386 F. Supp. 866 (S.D. Fla. 1974). See also SEC v. Johnson, SEC Litigation Release No. 7031 (Aug. 5, 1975), 7 SEC DoCKET 534 (1975) (defendant consented to order requiring him to return the proceeds from sale of memberships in "The Money Machine").

139. 386 F. Supp. at 872 .

140. Id at $872-74$.

141. Id. at 874 .

142. Id. at 880 (emphasis added). 
who purchased IDRs, as shown by the accounting. There was no mention by the court of giving credit to the defendants for any costs that would have been incurred in acquiring and selling the IDRs by the broker, including the price of the securities. The court's only concern was with establishing an adequate fund from which the victims of this "diabolical" scheme could recoup their lost proceeds.

\section{B. Tipper Liability}

Another example of an expansion of the disgorgement concept to fit the situation at hand is tipper liability for tippee profits. In Texas Gulf Sulphur the Second Circuit was confronted with the contention of defendant Darke, a geologist for Texas Gulf Sulphur, that the lower court's decision to require him to pay back not only his own profits but also the profits which his tippees had derived from their insider trading was a penalty assessment. ${ }^{143}$ The court did not deny that an additional hardship was imposed on Darke. Nevertheless, it accepted the Commission's rationale in requiring disgorgement of tippee profits as well, saying:

[W]ithout such a remedy, insiders could easily evade their duty to refrain from trading on the basis of inside information. Either the transactions so traded could be concluded by a relative or an acquaintance of the insider, or implied understandings could arise under which reciprocal tips between insiders in different corporations could be given. ${ }^{144}$

This resolution has been both criticized ${ }^{145}$ and supported. ${ }^{146}$ From the standpoint of deterrence and the effectiveness of the disgorgement remedy, it seems preferable to focus recovery efforts on the tipper-the source of the confidential information and the source of its abuse-rather than on the tippee, who merely represents an effect of the problem. For that reason, equity imposes an additional burden on the defendant even though the result extends the disgorgement remedy beyond its normal limits.

\section{The Mechanics of Disgorgement}

Obtaining a disgorged sum from one accused of having or found to have violated anti-fraud provisions of the securities laws may often prove easier than overcoming the problem of distributing that sum fairly and rationally. In the Texas Gulf Sulphur case the district court approved the SEC's proposal that payments be made by the defendants to the Texas Gulf Sulphur Company, to be placed in an interest-bearing escrow account for a

143. 446 F.2d at 1308 . See text accompanying notes $80-81$ supra.

144. Id.

145. Comment, supra note 49 , at 963 n.101.

146. Comment, Deterrence of Tippee Trading Under Rule 10b-5, 38 U.CHI. L. REv. 372, 379 (1971). 
period of five years, subject to disposition by the court on application from the SEC, any interested party, or on the court's own motion. In the event that any defendant incurred a liability in any judgment or settlement in a similar private action commenced before the Commission's action, that liability would be applied against the defendant's disgorged payment. At the end of the five year period, any money remaining would become the property of Texas Gulf Sulphur. ${ }^{147}$ Such a seemingly straightforward plan for the distribution of disgorged payments was subject to the potential for a great deal of complexity and misunderstanding. Private claims in the Texas Gulf Sulphur affair far exceeded the defendants' disgorged payments to the escrow fund. There was no procedure established for an orderly and proportionate distribution to competing claimants; the matter was merely left to the court's ad hoc review.

In SEC v. Golconda Mining Co. ${ }^{148}$ the defendants attempted to recover their disgorged profits when it appeared that there were not enough claims by injured investors to absorb the fund. The defendants had consented to pay some $\$ 47,000$ to a court-appointed trustee after the SEC charged them with trading on inside information. Rather than simply dividing the disgorged proceeds among all those who had sold their stock during the period of the alleged violation, the trustee was ordered to identify the particular sellers from whom defendants had made their illicit purchases. After diligent efforts, the trustee was unable to locate all those entitled to payment.

The judgment provided that in such an event defendants were entitled to reimbursement for the trustee's fees and expenses with disposition of the balance of the disgorged fund subject to the court's discretion. Though the defendants had never admitted their wrongdoing, the court assumed as much, and refused to return their unclaimed profits. The money was transferred instead to the registry of the court, to be held for the perpetual benefit of those persons entitled to payment or their successors in interest. ${ }^{149}$ The court concluded that it would be contrary to public policy to allow the violators to profit, even belatedly, from their fraud. ${ }^{150}$

Previously disgorged funds were successfully recovered by the defendant in SEC v. General Host Corp. ${ }^{151}$ however. Judge Weinfeld, who ruled in the SEC's favor in Golconda, concluded in General Host that a $\$ 300,000$ disgorgement fund established by one of the defendants, Allen \& Company,

147. 312 F. Supp. at 93 . In this instance equity takes on an added twist by granting a contingent recovery to the Texas Gulf Sulphur Company, one of the wrongdoers.

148. 327 F. Supp. 257 (S.D.N.Y. 1971).

149. The funds were to be held by the court pursuant to 28 U.S.C. $\$ \$ 2041-2042$ (1970) which govern the deposit and withdrawal of monies paid into any court of the United States.

150. 327 F. Supp. at 259-60.

151. 73 Civ. 275 (S.D.N.Y. Aug. 29, 1977). 
as part of a consent judgment with the SEC should be returned to it. Allen sought to recover its fund when a private class action against it and other defendants that had largely tracked the SEC's action failed to establish its claim of securities violations. ${ }^{152}$ The SEC and Allen were in accord that no other lawsuit was likely to be filed in the wake of the unsuccessful class action and in light of the applicable statutes of limitation.

The Commission argued, nevertheless, that the trust fund should not be returned to Allen but should rather be donated to charity. In support of this argument the SEC claimed first that this is what the parties contemplated when drafting the settlement agreement and, second, that Allen should not be given back the profits it derived from violations of the federal securities laws. Allen disputed the SEC's version of what the parties had contemplated and further contended that the money ought to be returned, since any other disposition would constitute a penalty against it.

Judge Weinfeld found that there was no prior understanding between the SEC and Allen to the effect that the trust funds, if not dispersed to private litigants in actions arising out of the alleged violations, would then be donated to charity. Absent the defendant's consent in an agreement with the SEC to such a disposition, the court found itself powerless to direct that the disgorged funds be distributed to charity. In dealing with the SEC's second argument, the court noted, in reversing its previous position expressed in Golconda, that the settlement recited Allen's consent to the disgorgement "without admitting or denying any of the allegations of the amended complaint" and "that there ha[d] been no finding or [sic] fact or . . . adjudicated matter with respect to any matter alleged in or arising out of the amended complaint . . . ."153 The court then stated that "[i]n considering the disposition of the fund, the Court must accept the consent decree 'as it is written, and not as it might have been written had the plaintiff established his factual claims and legal theories in litigation.' "154

Though Golconda was not dealt with in the General Host decision, it seems the contrary outcome in the latter case is distinguishable in that the defendant litigated the issue of its liability and was found not liable prior to seeking a return of its funds. In Golconda the defendants sought the return of their funds as soon as the trustee had exhausted his attempts to locate the remaining rightful claimants. There was no judicial determination that the defendants were not liable for the violations alleged by the SEC.

The court, however, chose not to explain its decision in these terms. The position Judge Weinfeld took in General Host suggests that a fund for private claimants established pursuant to an SEC consent settlement niay

152. Spielman v. General Host Corp., 402 F. Supp. 190 (S.D.N.Y. 1975) (Weinfeld, J.), aff'd, 538 F.2d 39 (2d Cir. 1976).

153. SEC v. General Host Corp., Slip op. at 10 (quoting the prior consent judgment).

154. Id. at 11 (citing United States v. Arjour \& Co., 402 U.S. 673, 682 (1971)). 
one day be returned to the defendant who neither admits nor denies liability in consenting to create the fund, provided he can show the court by means of the statutes of limitations or otherwise that no valid claims will be made in the future against the fund.

It is at best uncertain, as Golconda and General Host demonstrate, that the defendant can eventually gain back what he gave up in the event that various complications prevent a complete distribution. On the other hand, steps can be taken to protect the defendant against losses to him beyond what is represented by the actual disgorgement. In Texas Gulf Sulphur an escrow account was established, which is presumably less expensive than the use of a trustee as in Golconda ${ }^{155}$ The SEC has also consented to a defendant serving as his own trustee, to be monitored by a third party. ${ }^{156}$ The defendant must also be protected against separate public and private recoveries for the same wrong. ${ }^{157}$ In addition, to the extent that any portion of the disgorged sum goes unclaimed for a period of time long enough to permit invocation of the applicable statute of limitations or laches, it would appear that the defendant is entitled to have any distribution costs paid by him reimbursed from the unclaimed amount (as in Golconda) as well as any other costs, such as attorneys' fees. If the judgment provides that the defendant may be reimbursed years later for some or all of his costs, that can hardly be said to undermine the deterrent effect of the earlier disgorgement. Furthermore, even if all his costs are eventually reimbursed, the defendant has nonetheless been permanently deprived of the profits which he paid into the disgorgement fund. ${ }^{158}$

\section{CONCLUSION}

It appears that the SEC's disgorgement remedy is likely to be employed even more widely in the future than it has been in the past. Recently, the

155. In SEC v. Blatt, [1975-1976 Transfer Binder] FED. SEC. L. REP. (CCH) I 95,281 at 98,445 (S.D. Fla. July 24, 1976), the trustee's costs were taxed against all of the defendants found liable for fraud, even though only one had to disgorge his profits.

156. SEC v. Downey, SEC Litigation Release No. 7084 (Sept. 12, 1975), 7 SEC DOCKET 895 (1975). But of. SEC v. Satenstein, SEC Litigation Release No. 6746 (Feb. 19, 1975), 6 SEC DOCKET 335 (1975) (defendants agreed to disgorge profits plus an additional 10\% to cover cost of administering the fund).

157. See SEC v. Drew National Corp., SEC Litigation Release No. 6995 (July 18, 1975), 7 SEC DOCKET 449 (1975) (disgorgement account maintained "for the purpose of providing a fund for payment of adjudicated or settled claims arising out of [defendants'] alleged insider trading"); SEC v. Stirling Homex Corp., SEC Litigation Release No. 6960 (July 2, 1975), 7 SEC DOCKET 370 (1975) (defendant agreed to disgorge profits pursuant to a plan to be determined by the court, providing that such disgorgement would await and be limited by the results of all civil actions pending with respect to the matters covered in the SEC complaint and all settlements which had been entered and satisfied by the defendant); SEC v. Texas GuIf Sulphur Co., 312 F. Supp. 77, 93 n.23 (S.D.N.Y. 1970).

158. Such an approach would not be appropriate, however, if the court and the SEC intend to depend on the defendant to locate those investors who are entitled to a share of the disgorgement fund. 
Commission sought and obtained the disgorgement of profits in an action where the defendant was not charged with a direct securities violation but rather with a violation of an SEC administrative order outstanding against him from prior securities violations. ${ }^{159}$ More far-reaching are the SEC's recent requests for monetary relief in its suits against corporate officials for unreported corporate payments. The Commission has filed a number of complaints against corporate officers which have alleged reporting, and not anti-fraud, violations, yet have sought relief which required the individual defendants to repay all corporate funds used for the illegal or improper payments. ${ }^{160}$

In boldly demanding this type of equitable remedy, the Commission has left by the wayside its two strongest arguments for convincing a court to exercise its equity powers in favor of disgorgement ancillary to injunctive relief: (1) that securities fraud deserves to be deterred by potent, effective measures; and (2) that a wrongdoer ought not to be permitted to retain the profits of his wrongdoing. The equitable considerations are far less compelling where there are only reporting violations. For one thing, investor losses caused by a company's failure to report improper payments, which may span a number of years, are surely more speculative and remote than those resulting from fraud. Furthermore, it would appear that the corporate officials who may have acted improperly did so primarily for the benefit of their corporations and only incidentally for themselves. Even at that, one could not say with much conviction that such officers acted illegally or failed to act because of personal avarice. Finally, the monetary recovery obtained by the SEC is no longer a function of the profits or gains, if any, realized by the defendants. Hence, the recoveries in such cases may appear rather arbitrary when held up against the differing degrees of culpability of the various defendants.

The Commission is nevertheless showing no reluctance to push a relatively novel remedy to new limits and into diverse areas. Thus, the courts may again be faced with questions as to how far the SEC can go in asserting its implied power to obtain broad monetary sanctions without the benefit of an explicit authorization from Congress.

159. SEC v. Fields, SEC Litigation Release No. 7102 (Sept. 26, 1975), 7 SEC DOCKET 1016 (1975) (defendant consented to an injunction against further violations of rule 2(e) of the SEC Rules of Practice and to disgorge all fees, compensation or other consideration which he had received since an earlier rule 2(e) action against him in which he was permanently barred from practice before the SEC [SEC Securities Act of 1933 Release No. 5404 (June 18, 1973), 2 SEC DOCKET 1 (1973)]).

160. See, e.g., SEC Complaints in SEC v. Ashland Oil, Inc., No. $75-0794$ (D.D.C. May 16, 1975); SEC v. Gulf Oil Corp., No. $75-0324$ (D.D.C. Mar. 11, 1975); SEC v. Minnesota Mining \& Mfg. Co., No. 3-75-29 (D. Minn. Jan. 30, 1975); SEC v. American Ship Building Co., No. 74-588 (D.D.C. Apr. 15, 1974). 